\author{
Ya.A. Vissurkhanova ${ }^{1,2}$, E.A. Soboleva ${ }^{2}$, N.M. Ivanova ${ }^{2}$, Z.M. Muldakhmetov ${ }^{2}$ \\ ${ }^{1}$ E.A. Buketov Karaganda State University, Kazakhstan; \\ ${ }^{2}$ LLP "Institute of Organic Synthesis and Coal Chemistry of Republic of Kazakhstan", Karaganda, Kazakhstan \\ (E-mail: yakhavisurkhanova@bk.ru)
}

\title{
Thermal and electrochemical reduction of nickel (II) ferrite under the influence of polymer stabilizers
}

\begin{abstract}
Nickel (II) ferrite samples have been prepared by co-precipitation of metal salts in an aqueous solution without and with the addition of polymer stabilizers (polyvinyl alcohol and polyvinylpyrrolidone) and further heat treatment at $500{ }^{\circ} \mathrm{C}, 700{ }^{\circ} \mathrm{C}$ and $900{ }^{\circ} \mathrm{C}$. Their structural-phase changes before and after using as catalysts in the electrohydrogenation of acetophenone were revealed by X-ray phase analysis. Morphological features of the obtained $\mathrm{NiFe}_{2} \mathrm{O}_{4}$ and $\mathrm{NiFe}_{2} \mathrm{O}_{4}+$ polymer samples were studied by electron microscopy. It has been established that the addition of polymer stabilizer into the co-precipitation medium and its partial preservation in the composition of precursors (metal hydroxides and oxides) and in the formed nickel (II) ferrite have a noticeable effect on the structural-phase constitutions of the samples prepared. Differences in the phase constitutions are also depend on the heat treatment temperature of these samples. It was shown that, in contrast to nickel ferrite synthesized without stabilizers, $\mathrm{NiFe}_{2} \mathrm{O}_{4}+$ polymer samples are partially reduced during heat treatment and additionally in an electrochemical system with the formation of Ni- and Fe-Ni-containing composites. The reduced samples of nickel (II) ferrite were tested for their ability to exhibit electrocatalytic properties in the electrohydrogenation of acetophenone. Their low electrocatalytic activity in this process was determined, which is presumably conditioned by the structure of Fe-Ni-alloy particles with iron content predominant, as well as by the presence of magnetite inhibited the activity of nickel particles.
\end{abstract}

Keywords: nickel (II) ferrite, co-precipitation method, heat treatment, electrochemical reduction, nickel and iron zero-valence particles, electrocatalytic hydrogenation, acetophenone.

\section{Introduction}

Ferrites are magnetic oxide metal compounds with the general structural formula $\mathrm{MFe}_{2} \mathrm{O}_{4}(\mathrm{M}=$ doubly charged metal ion, for example, $\mathrm{Cu}, \mathrm{Ni}, \mathrm{Co}, \mathrm{Zn}, \mathrm{Mn}, \mathrm{Mg}$, etc.), in which magnetic and electrical properties are combined peculiarly. It should be noted the ecological safety of these materials due to their high thermal stability (melting and decomposition temperatures above $1500-1700{ }^{\circ} \mathrm{C}$ ), lack of toxicity and insolubility in water.

Materials based on metal ferrites are widely used in instrument engineering, radio electronics, electrotechnical industry, in catalysis and other branches of science and technology. In catalysis, ferrites of transition metals (Co, Ni, $\mathrm{Cu}, \mathrm{Zn})$ and their mixed compositions have been successfully applied. The particle size of such catalysts is varied from $2 \mathrm{~nm}$ to several micrometers. Moreover, their magnetic properties allow easy to remove them from the reaction system and repeatedly use them practically without loss of catalytic activity [1]. In the literature, examples of the application of transition metal ferrites in catalytic reaction have been described, such as decomposition of methanol into $\mathrm{CO}$ and methane or $\mathrm{CO}$ and $\mathrm{H}_{2}$, oxidation of various alkenes, alkylation, dehydration, synthesis of quinoxaline derivatives, 1,4-dihydropyridine, etc. [2-4].

Nickel ferrite has an inverse spinel structure, when half of the iron cations occupies tetrahedral positions in the crystal cell, while the other half and all $\mathrm{Ni}^{2+}$ cations occupy octahedral positions. The location of nickel cations in the crystal structure of $\mathrm{NiFe}_{2} \mathrm{O}_{4}$ is closely related to its magnetic properties. Nickel ferrite shows itself as a super-paramagnet and applies as gas-sensors, magnetic fluids, catalysts, magnetic storage systems, photomagnetic materials, site-specific drug delivery, microwave devices, etc. [5]. Recently the possibility of monodispersed $\mathrm{NiFe}_{2} \mathrm{O}_{4}$ nanospheres using as a high-performance pseudo-capacitor [6] and electrode material for a super-capacitor has been established [7].

Transition metal ferrites are produced by various methods, including thermal decomposition, microemulsion method, co-precipitation, hydrothermal, solvothermal and biological methods [8-11]. Low temperature co-precipitation methods [12] and sol-gel processes [13], including the creation of complexes with the addition of surfactants, have such advantages as a lower calcining temperature as compared to solid-phase synthesis, simplicity of fulfilment, high che $7 \mathrm{mical}$ homogeneity and purity of the materials obtained. The incorporation of various type additives, which promote the formation of doped structures, into the base system composition 
is considered as a one of the chemical methods for improving the structural and magnetic properties of the resulting ferrites. In research works [14-15], the effect of an organic stabilizer on crystallinity, phase constitution and morphological features of nickel ferrite nanoparticles has been studied.

The purpose of this work is to study the structural-phase transformations of nickel (II) ferrite samples synthesized without and in the presence of a polymer stabilizer during their heat treatment, as well as the possibility of their electrochemical reduction with the formation of $\mathrm{Ni}^{0}-\mathrm{Fe}^{0}$-containing composites and their electrocatalytic activity in electrohydrogenation of acetophenone (APh) as a model compound.

\section{Experimental}

Dispersed nickel (II) ferrite $\left(\mathrm{NiFe}_{2} \mathrm{O}_{4}\right)$ was synthesized by the co-precipitation method from aqueous solutions of metal salts according to the following procedure. A stoichiometric quantities of nickel nitrate $\left(\mathrm{Ni}\left(\mathrm{NO}_{3}\right)_{2} \cdot 6 \mathrm{H}_{2} \mathrm{O}\right)$ and iron chloride $\left(\mathrm{FeCl}_{3} \cdot 6 \mathrm{H}_{2} \mathrm{O}\right)$ (in a ratio of 1:2) were dissolved in $300 \mathrm{ml}$ of distilled water and the mixture was stirred for $30 \mathrm{~min}$ at $40{ }^{\circ} \mathrm{C}$. Next $1 \mathrm{M} \mathrm{NaOH}$ solution was poured dropwise to $\mathrm{pH}=12$ under constant stirring. The obtained brown precipitate was filtered and washed with distilled water heated up to $50{ }^{\circ} \mathrm{C}$. It was dried at $80^{\circ} \mathrm{C}$. The resulting dark brown powder was divided into three equal parts and heat treated at $500{ }^{\circ} \mathrm{C}, 700{ }^{\circ} \mathrm{C}$ and $900{ }^{\circ} \mathrm{C}$ for 2 hours. It was crushed in a Tube Mill control at the same speed and duration of grinding.

Nickel (II) ferrite samples with the addition of water-soluble polymers (polyvinyl alcohol (PVA) and polyvinylpyrrolidone (PVP)) were obtained by dissolving metal salts in a $3 \%$ polymer solution and co-precipitating by sodium hydroxide. The filtered precipitates were washed with distilled water having room temperature. After drying the composites were also thermally treated at $500{ }^{\circ} \mathrm{C}, 700{ }^{\circ} \mathrm{C}$ and $900{ }^{\circ} \mathrm{C}$ during 2 hours. The $\mathrm{NiFe}_{2} \mathrm{O}_{4}$ samples produced after heat treatment were crushed in a Tube Mill control.

The nickel and iron metals content in the filtrates after co-precipitation procedure was determined by a selective complexometric titration [16-17]. According to the results of titration the lack of metal cations in the obtained transparent filtrates was established, which indicate of their practically complete precipitation in the form of the corresponding hydroxides or oxides.

The structure and phase constitution of the synthesized nickel ferrite samples were studied by X-ray diffraction (XRD) analysis on a DRON-2 diffractometer. The morphological features of the nickel ferrite samples were scanned on the TESCAN MIRA 3 LMU electron microscope.

The ability of $\mathrm{NiFe}_{2} \mathrm{O}_{4}$ samples prepared to electrochemical reduction and manifestation of electrocatalytic properties by the Fe-Ni-composites were tested in the electrochemical system. The electrocatalytic activity of $\mathrm{Fe}-\mathrm{Ni}$-composites was studied in the process of electrohydrogenation of acetophenone, the product of which is methyl phenyl carbinol (MPhC), a well-known fragrant substance with a wide range of applications. Experiments were carried out in an electrochemical diaphragm cell in alcohol-aqueous-alkaline catholyte at a current of $1.5 \mathrm{~A}$, and a temperature of $30^{\circ} \mathrm{C}$. The cathode was a copper plate that was closely contacted the bottom of the cell and served as a substrate for the applied nickel ferrite particles (by a weight of $1 \mathrm{~g}$ ), platinum gauze was used as an anode. The initial concentration of APh was $0.198 \mathrm{M}$. The nickel ferrite samples deposited on the cathode were fixed on it by an inner magnet and saturated with hydrogen (stage I). During hydrogen saturation the electrochemical reduction of metal cations could be occur. The duration of this stage (until the ratio of the evolved gases is set to $\mathrm{V}\left(\mathrm{H}_{2}\right): \mathrm{V}\left(\mathrm{O}_{2}\right)=2: 1$ ) was varied from 10 to 200 minutes. Then organic compound was injected into the catholyte and its electrocatalytic hydrogenation carried out (stage II). The volume of hydrogen $\left(V_{H_{2}}\right)$ absorbed on the stage $\mathrm{I}$, and also the hydrogenation rate $(\mathrm{W})$, hydrogen utilization coefficient $(\eta)$ and conversion of the hydrogenated compound $(\alpha)$ for the stage II were calculated from the volumes of gases evolved (oxygen and hydrogen). The hydrogenation products were extracted from the catholyte with chloroform, and the extracts were analyzed on a Kristall-5000.1 chromatograph.

\section{Results and Discussion}

Structural-phase changes of $\mathrm{NiFe}_{2} \mathrm{O}_{4}$ samples after heat treatment, and after electrochemical reduction and use them in electrohydrogenation of $\mathrm{APh}$ are studied by X-ray phase analysis (XRD). The X-ray diffraction patterns of nickel ferrite samples prepared without and with addition of polymer stabilizers are shown in Figures $1-3$.

At the co-precipitation of nickel nitrates and iron hydroxide in an aqueous solution the following reaction occurs:

$$
\mathrm{Ni}\left(\mathrm{NO}_{3}\right)_{2}+2 \mathrm{FeCl}_{3}+8 \mathrm{NaOH} \rightarrow \mathrm{Ni}(\mathrm{OH})_{2} \downarrow+2 \mathrm{Fe}(\mathrm{OH})_{3} \downarrow+6 \mathrm{NaCl}+2 \mathrm{NaNO}_{3}
$$


Then the dried powder of co-precipitated hydroxides of both metals is subjected to heat treatment at $500{ }^{\circ} \mathrm{C}, 700{ }^{\circ} \mathrm{C}$ и $900{ }^{\circ} \mathrm{C}$ for 2 hours. Upon reaching a temperature of $300{ }^{\circ} \mathrm{C}$ metal oxides are formed from metal hydroxides:

$$
\mathrm{Ni}(\mathrm{OH})_{2}+2 \mathrm{Fe}(\mathrm{OH})_{3} \stackrel{300^{\circ} \mathrm{C}}{\longrightarrow} \mathrm{NiO}+\mathrm{Fe}_{2} \mathrm{O}_{3}+4 \mathrm{H}_{2} \mathrm{O}
$$

At $500{ }^{\circ} \mathrm{C}$ nickel and iron oxides react with the formation of nickel (II) ferrite:

$$
\mathrm{NiO}+\mathrm{Fe}_{2} \mathrm{O}_{3} \stackrel{500^{\circ} \mathrm{C}}{\longrightarrow} \mathrm{NiFe}_{2} \mathrm{O}_{4} \downarrow
$$

The formation of the above phases is confirmed by XRD patterns of nickel ferrite synthesized without addition of a polymer stabilizer (Figure 1, 1a). According to the XRD results, it was found that the samples of nickel ferrite heat treated contain crystalline phases of nickel (II) ferrite, as well as nickel oxide (NiO) and hematite $\left(\alpha-\mathrm{Fe}_{2} \mathrm{O}_{3}\right)$ with low intensity peaks, as shown in Figure 1.

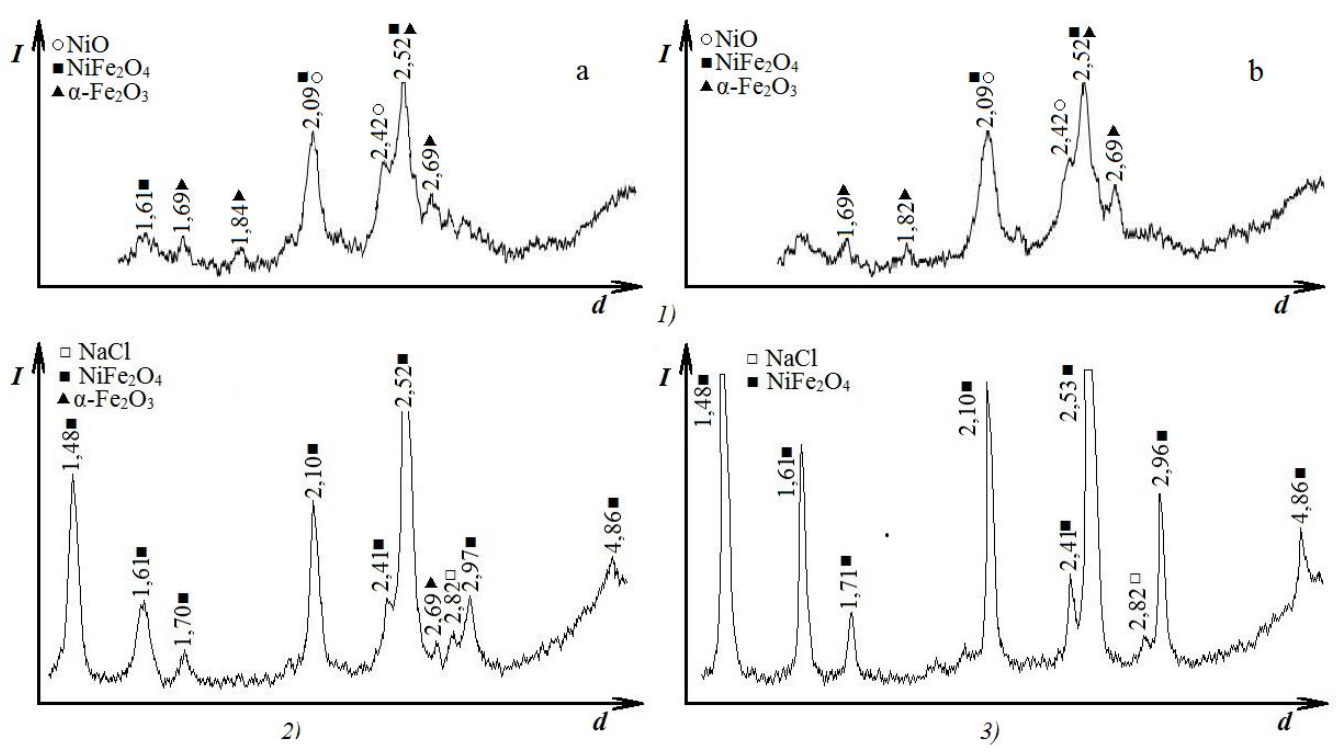

Figure 1. XRD patterns of $\mathrm{NiFe}_{2} \mathrm{O}_{4}$ samples treated at $500{ }^{\circ} \mathrm{C}$ before $(a)$ and after $(b)$ electrohydrogenation of $\mathrm{APh}(1)$, at $700{ }^{\circ} \mathrm{C}(2)$ and $900{ }^{\circ} \mathrm{C}(3)$

As follows from the given X-ray diffraction patterns, as the heat treatment temperature rises, the crystallinity of the present phases also increases. It has been established that in the compositions of all $\mathrm{NiFe}_{2} \mathrm{O}_{4}$ samples after electrochemical reduction attempt and their use as electrocatalysts, the phase transformations do not occur (e.g. Figures 1, $1 a$ and $1 b$ ). This indicates the inability of nickel (II) ferrite to electrochemical reduction under specified conditions and to manifestation of electrocatalytic properties in the studied process.

The addition of a polymer stabilizer into the co-precipitation reaction medium and its partial conservation in the composition of precipitated metal hydroxides and oxides have a noticeable effect on the structural phase constitution of nickel (II) ferrite samples heat treated (Fig. 2 and 3). Differences in phase constitution are also depended on the heat treatment temperature of these samples. Thus, the crystalline phases of metallic nickel $\left(\mathrm{Ni}^{0}\right)$ reduced from nickel ferrite by the products of PVA thermal decomposition appear in the constitution of the $\mathrm{NiFe}_{2} \mathrm{O}_{4}+$ PVA sample treated at $500{ }^{\circ} \mathrm{C}$ (Figure 2, 1a):

$$
3 \mathrm{NiFe}_{2} \mathrm{O}_{4}+4 \mathrm{CO} \rightarrow 3 \mathrm{Ni}^{0}+2 \mathrm{Fe}_{3} \mathrm{O}_{4}+4 \mathrm{CO}_{2}
$$

In this case, the release of nickel from the $\mathrm{NiFe}_{2} \mathrm{O}_{4}$ crystal lattice is accompanied by the formation of magnetite $\left(\mathrm{Fe}_{3} \mathrm{O}_{4}\right)$. The crystalline phases of nickel are saved in this sample after the electrochemical reduction (Fig. 2, 1 b). The thermal treatment of a $\mathrm{NiFe}_{2} \mathrm{O}_{4}+$ PVA sample at $700^{\circ} \mathrm{C}$ leads to partial reduction of not only nickel, but also iron:

$$
\mathrm{Fe}_{3} \mathrm{O}_{4}+4 \mathrm{CO} \rightarrow 3 \mathrm{Fe}^{0}+4 \mathrm{CO}_{2}
$$

which form the Fe-Ni-alloy (Fig. 2, 2a). 

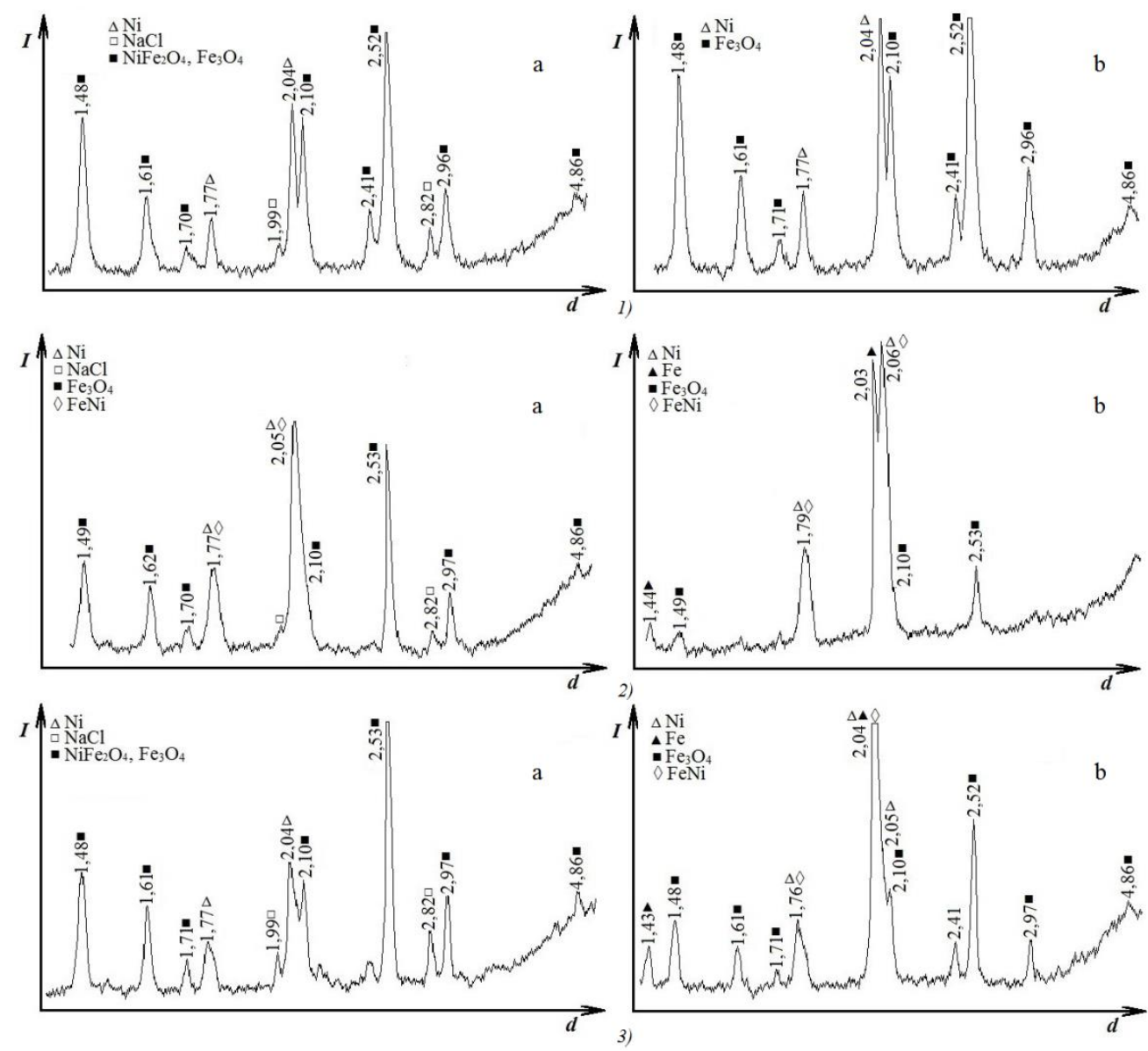

Figure 2. XRD patterns of $\mathrm{NiFe}_{2} \mathrm{O}_{4}+$ PVA samples before $(a)$ and after $(b)$ electrohydrogenation of $\mathrm{APh}$ treated at $500{ }^{\circ} \mathrm{C}(1), 700{ }^{\circ} \mathrm{C}(2)$ and $900{ }^{\circ} \mathrm{C}(3)$

After electrochemical reduction the amount of reduced iron and its alloy with nickel increases with a sharp decrease in the crystalline phases of magnetite. The constitution of the $\mathrm{NiFe}_{2} \mathrm{O}_{4}+\mathrm{PVA}\left(900{ }^{\circ} \mathrm{C}\right)$ sample after heat treatment (Fig. 2, 3a) is almost similar to the constitution of the $\mathrm{NiFe}_{2} \mathrm{O}_{4}+\mathrm{PVA}\left(500^{\circ} \mathrm{C}\right)$ sample (Fig. 2, 1a), but crystalline phases of iron and Fe-Ni-alloy additionally appear during its electrochemical reduction. In so doing, magnetite also present in the composition of this sample.

Nickel (II) ferrite samples synthesized in the presence of PVP and thermally treated at the same temperatures $\left(\mathrm{NiFe}_{2} \mathrm{O}_{4}+\mathrm{PVP}\right)$ have similar phase constitutions (Fig. 3). The effect of this polymer stabilizer on the electrochemical reduction of both metals from $\mathrm{NiFe}_{2} \mathrm{O}_{4}+$ PVP samples has a character similar to the PVA effect. The most full electrochemical reduction of nickel (II) ferrite is achieved in the case of its preliminary treatment at $700{ }^{\circ} \mathrm{C}$ (Fig. 3, 2a, 2b). As a result, the composite with Fe-Ni-alloy, metallic iron and $\mathrm{Fe}_{3} \mathrm{O}_{4}$ residue in its constitution is formed.

The structure and morphological features of heat treated nickel (II) ferrite samples were studied by electron microscopy using two electron detectors (SE, BSE). Obviously, in the BSE images the light areas are metal formations $\left(\mathrm{Fe}^{0}, \mathrm{Ni}^{0}, \mathrm{Fe}-\mathrm{Ni}\right.$-alloys), the darker ones are oxygen-containing metal compounds and impurities in the sample (e.g. $\mathrm{NaCl})$.

In the $\mathrm{NiFe}_{2} \mathrm{O}_{4}+\mathrm{PVA}\left(700{ }^{\circ} \mathrm{C}\right)$ sample after electrochemical reduction and electrohydrogenation of $\mathrm{APh}$ (Fig. 4, b), light areas are significantly more, than in the sample after heat treatment (Fig. 4, a), which confirmes the passage of additional reduction of both metals from $\mathrm{NiFe}_{2} \mathrm{O}_{4}$ and $\mathrm{Fe}_{3} \mathrm{O}_{4}$ formation in the electrochemical system. Meanwhile the oxygen content significantly decreases and the iron content increases. If after heat treatment the particles of the resulting Fe-Ni-alloys had compositions with the ratio of metals Fe: $\mathrm{Ni}=3: 1$, 1:1 and even 1:1.5 (i.e. with a high nickel content) according to the energy-dispersive X-ray spectroscopy (EDS) analysis, then after electrochemical reduction these ratios changed to 6:1 and 5:1. The distribution of metals in the surface layer of particles is also different (Fig. 5): iron is densely distributed over the entire surface and nickel is more often distributed along the particle edge and in separate coagulates. 

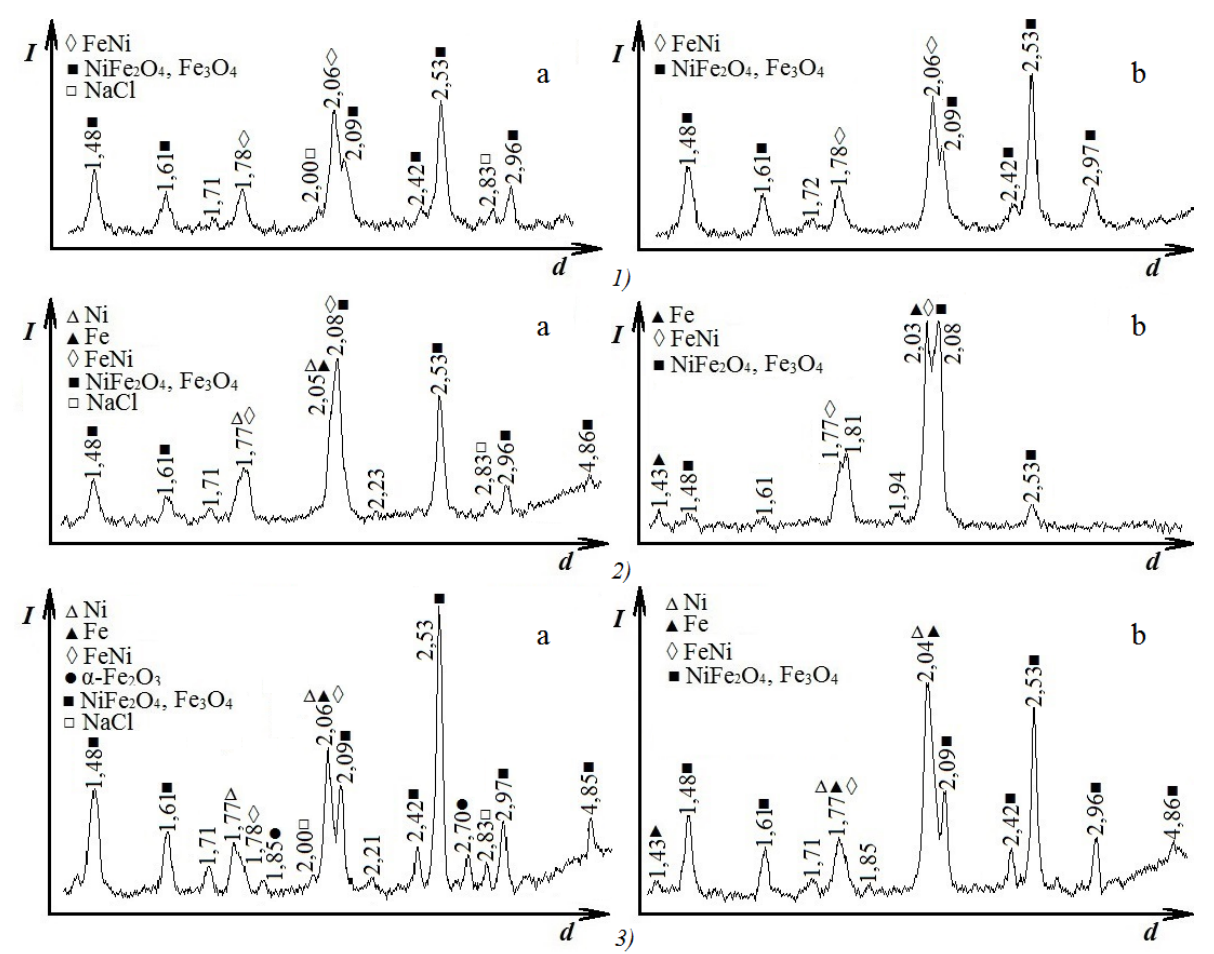

Figure 3. XRD patterns of $\mathrm{NiFe}_{2} \mathrm{O}_{4}+\mathrm{PVP}$ samples before $(a)$ and after $(b)$ electrohydrogenation of APh treated at $500{ }^{\circ} \mathrm{C}(1), 700{ }^{\circ} \mathrm{C}(2)$ and $900{ }^{\circ} \mathrm{C}(3)$
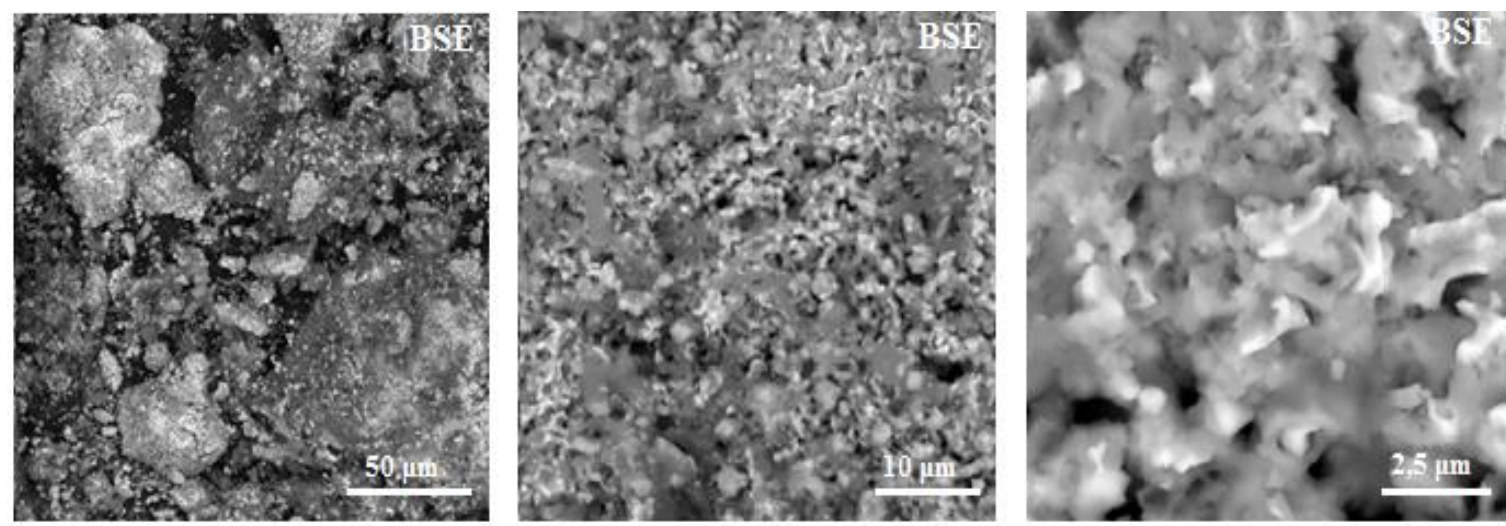

a)
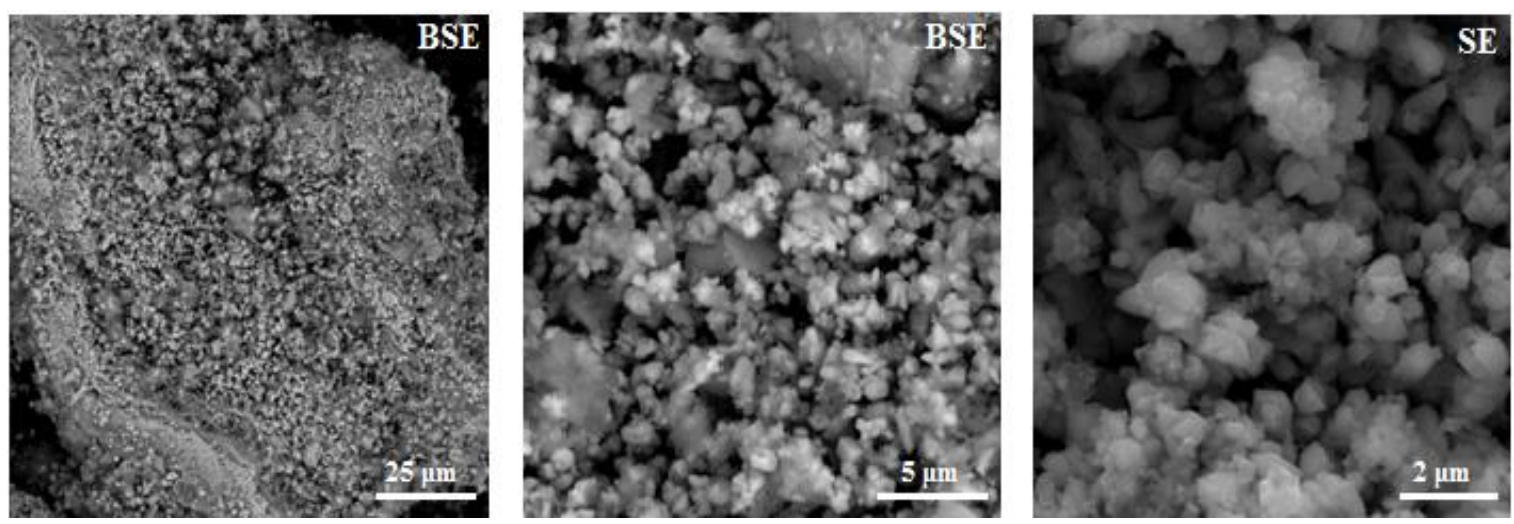

b)

Figure 4. Micrographs of $\mathrm{NiFe}_{2} \mathrm{O}_{4}+\mathrm{PVA}\left(70{ }^{\circ} \mathrm{C}\right)$ sample after heat treatment $(a)$ and after electrocatalytic hydrogenation of $\mathrm{APh}(b)$ 


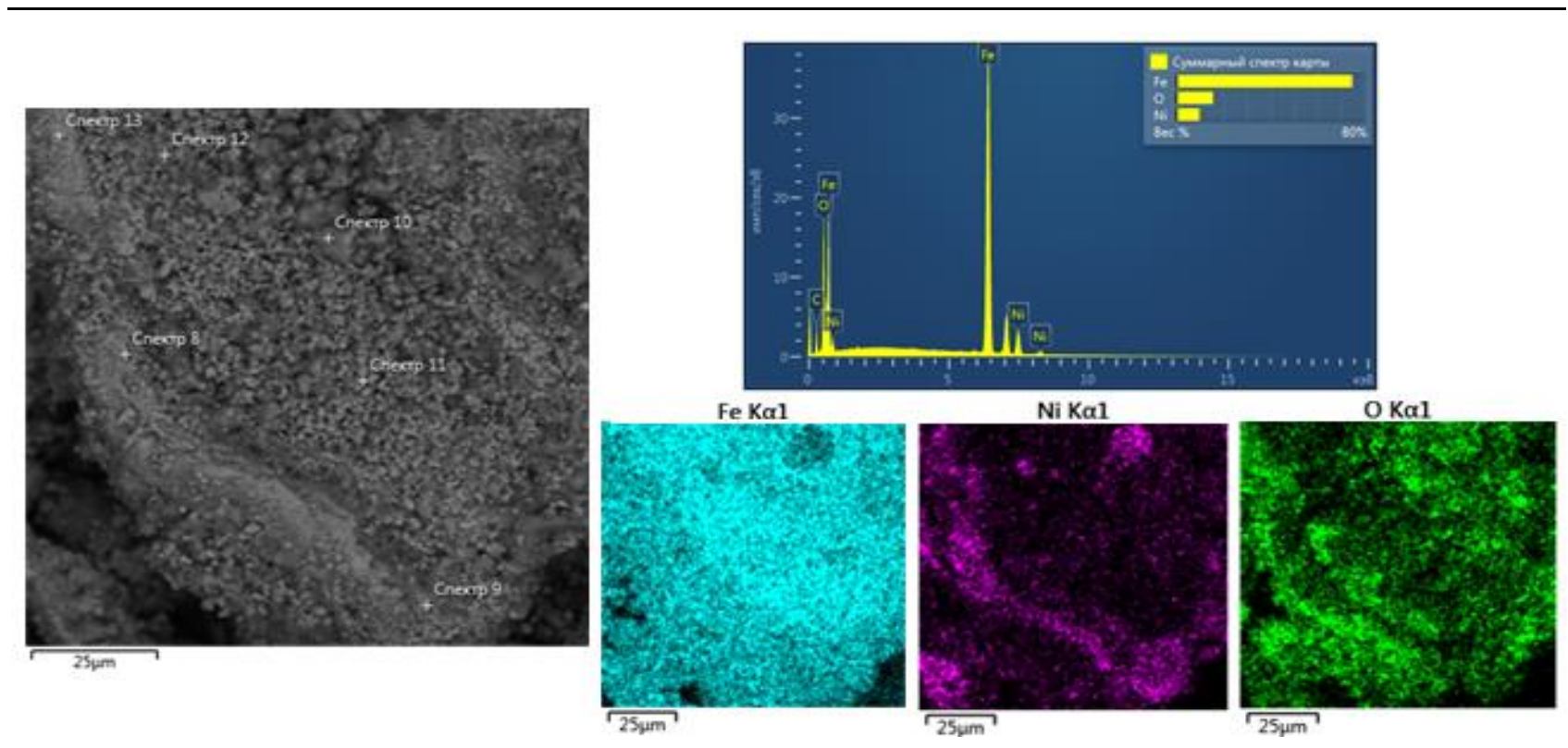

Figure 5. EDS analysis of $\mathrm{NiFe}_{2} \mathrm{O}_{4}+\mathrm{PVA}\left(700^{\circ} \mathrm{C}\right)$ sample particles after electrocatalytic hydrogenation of $\mathrm{APh}$

All the nickel (II) ferrite samples synthesized without and with polymer stabilizers and heat treated were investigated for their ability to electrochemical reduction and manifestation of electrocatalytic properties in the electrohydrogenation of acetophenone:

$$
\mathrm{C}_{6} \mathrm{H}_{5}-\mathrm{C}(\mathrm{O})-\mathrm{CH}_{3}+2 \mathrm{H}^{+}+2 \mathrm{e}^{-} \rightarrow \mathrm{C}_{6} \mathrm{H}_{5}-\mathrm{CH}(\mathrm{OH})-\mathrm{CH}_{3}
$$

The main resulting data of both stages of electrochemical experiments are given in Table 1. First the electrochemical reduction of $\mathrm{NiFe}_{2} \mathrm{O}_{4}$ samples was carried out, then electrocatalytic hydrogenation of $\mathrm{APh}$ on forming $\mathrm{Fe}-\mathrm{Ni}$ composites as electrocatalysts. For comparison, the results of electrochemical reduction of $\mathrm{APh}$ on a $\mathrm{Cu}$ cathode, which proceeds with a relatively low process rate and conversion of the hydrogenated substance, not exceeding 22,1\%, are also presented here. In addition to methyl phenyl carbinol (equation (1)), dimeric compounds were formed in the process.

$\mathrm{Tab} 1 \mathrm{e} 1$

Electrochemical reduction of synthesized nickel (II) ferrite samples and electrocatalytic hydrogenation of acetophenone in their presence

\begin{tabular}{|l|c|c|c|c|c|c|c|}
\hline \multirow{2}{*}{ Nickel ferrite } & \multicolumn{2}{|c|}{$\begin{array}{c}\text { Metal content in } 1 \mathrm{~g} \\
\text { of a ferrite sample, } \mathrm{g}\end{array}$} & \multicolumn{2}{c|}{$\begin{array}{c}\text { Electrochemical } \\
\text { reduction of ferrite }\end{array}$} & \multicolumn{3}{c|}{$\begin{array}{c}\text { Electrocatalytic hydrogenation } \\
\text { of acetophenone }\end{array}$} \\
\cline { 2 - 8 } & $\mathrm{Ni}$ & $\mathrm{Fe}$ & $\tau, \mathrm{min}$ & $V_{\mathrm{H} 2}, \mathrm{ml}$ & $\begin{array}{c}\mathrm{W}, \mathrm{ml} \mathrm{H}_{2} / \mathrm{min} \\
(\alpha=0,25)\end{array}$ & $\eta, \%$ & $\alpha, \%$ \\
\hline $\mathrm{Cu}$ cathode & - & - & - & - & 1,0 & 6,9 & 22,1 \\
\hline $\mathrm{NiFe}_{2} \mathrm{O}_{4}\left(500^{\circ} \mathrm{C}\right)$ & 0.245 & 0.467 & 40 & 13.0 & 0.0 & 0.0 & 0.0 \\
$\mathrm{NiFe}_{2} \mathrm{O}_{4}\left(700^{\circ} \mathrm{C}\right)$ & 0.252 & 0.481 & 20 & 8.8 & 0.0 & 0.0 & 0.0 \\
$\mathrm{NiFe}_{2} \mathrm{O}_{4}\left(900{ }^{\circ} \mathrm{C}\right)$ & 0.256 & 0.488 & 20 & 8.9 & 0.0 & 0.0 & 0.0 \\
\hline $\mathrm{NiFe}_{2} \mathrm{O}_{4}+\mathrm{PVA}\left(500^{\circ} \mathrm{C}\right)$ & 0.224 & 0.426 & 20 & 8.6 & 0.0 & 0.0 & 8.7 \\
$\mathrm{NiFe}_{2} \mathrm{O}_{4}+\mathrm{PVA}\left(700^{\circ} \mathrm{C}\right)$ & 0.245 & 0.467 & 140 & 108.1 & 0.0 & 0.0 & 8.7 \\
$\mathrm{NiFe}_{2} \mathrm{O}_{4}+\mathrm{PVA}\left(900^{\circ} \mathrm{C}\right)$ & 0.265 & 0.506 & 160 & 90.4 & 0.9 & 7.9 & 48.2 \\
\hline $\mathrm{NiFe}_{2} \mathrm{O}_{4}+\mathrm{PVP}\left(500^{\circ} \mathrm{C}\right)$ & 0.236 & 0.450 & 50 & 13.3 & 0.0 & 0.0 & 0.0 \\
$\mathrm{NiFe}_{2} \mathrm{O}_{4}+\mathrm{PVP}\left(700^{\circ} \mathrm{C}\right)$ & 0.288 & 0.549 & 200 & 114.7 & 1.0 & 8.8 & 47.7 \\
$\mathrm{NiFe}_{2} \mathrm{O}_{4}+\mathrm{PVP}\left(900^{\circ} \mathrm{C}\right)$ & 0.285 & 0.544 & 110 & 52.5 & 1.1 & 10.0 & 63.5 \\
\hline
\end{tabular}

The carrying out of the stage of electrochemical reduction of nickel (II) ferrite samples can be controlled by the volumes of absorbed hydrogen. According to data of Table $1, \mathrm{NiFe}_{2} \mathrm{O}_{4}$ samples prepared without the participation of polymers and thermally treated practically do not absorb hydrogen in the first stage, i.e. they are not reduced electrochemically. During the preliminary heat treatment these samples also were not reduced, and their constitutions were contained mainly crystalline phases of $\mathrm{NiFe}_{2} \mathrm{O}_{4}$ (Fig. 1). The same crystalline 
phases remain in their constitutions even after attempts to reduce them in the electrochemical system and, as can be seen from the data in Table 1, they do not exhibit electrocatalytic activity during the electrohydrogenation of $\mathrm{APh}$ - the second stage. The electrochemical reduction of APh does not pass in the presence of magnetic powder of nickel ferrite because it has not electrocatalytic properties, and covers the surface of the copper cathode holding onto it by an external magnet.

It has been established by the XRD analyzes that the $\mathrm{NiFe}_{2} \mathrm{O}_{4}+$ polymer samples are partially reduced during heat treatment by the polymer decomposition products, and their additional reduction occurs in the electrochemical system (Fig. 2 and 3):

$$
\begin{gathered}
3 \mathrm{NiFe}_{2} \mathrm{O}_{4}+2 \mathrm{e}^{-}+8 \mathrm{H}^{+} \rightarrow 3 \mathrm{Ni}^{0}+2 \mathrm{Fe}_{3} \mathrm{O}_{4}+4 \mathrm{H}_{2} \mathrm{O} \text { (For samples treated at } 500{ }^{\circ} \mathrm{C} \text { ) } \\
\mathrm{NiFe}_{2} \mathrm{O}_{4}+8 \mathrm{e}^{-}+8 \mathrm{H}^{+} \rightarrow \mathrm{Ni}^{0}+2 \mathrm{Fe}^{0}+4 \mathrm{H}_{2} \mathrm{O} \text { (For samples treated at } 700{ }^{\circ} \mathrm{C} \text { and } 900{ }^{\circ} \mathrm{C} \text { ) } \\
\mathrm{Fe}_{3} \mathrm{O}_{4}+6 \mathrm{e}^{-}+8 \mathrm{H}^{+} \rightarrow 3 \mathrm{Fe}^{0}+4 \mathrm{H}_{2} \mathrm{O} \text { (For samples treated at } 700{ }^{\circ} \mathrm{C} \text { and } 900{ }^{\circ} \mathrm{C} \text { ) }
\end{gathered}
$$

As can be seen from values of absorbed hydrogen volumes given in Table 1, the samples with heat treatment at $700{ }^{\circ} \mathrm{C}$ and $900{ }^{\circ} \mathrm{C}$ undergo additional electrochemical reduction. However, only one sample $\left(\mathrm{NiFe}_{2} \mathrm{O}_{4}+\mathrm{PVA}\left(900^{\circ} \mathrm{C}\right)\right)$ among the samples prepared with PVA exhibits the electrocatalytic activity and only in relation to the APh conversion - it increases to $48 \%$ (Table 1). The $\mathrm{NiFe}_{2} \mathrm{O}_{4}+\mathrm{PVP}$ samples partially reduced thermally are also reduced additionally in the electrochemical system (mainly, samples treated at $700{ }^{\circ} \mathrm{C}$ и $900{ }^{\circ} \mathrm{C}$ ) and they show the electrocatalytic activity slightly higher than samples with PVA (Table 1).

The low electrocatalytic activity of nickel ferrite samples synthesized in the presence of polymers and partially reduced during heat treatment and additionally in an electrochemical system can be explained as follows. Firstly, in samples of $\mathrm{NiFe}_{2} \mathrm{O}_{4}+$ polymer thermally treated at $500^{\circ} \mathrm{C}$, the reduction of nickel (II) cations (Fig. 2,1) is accompanied by the formation of magnetite (reaction equation (7)). It is possible that the magnetite completely closes the reduced nickel, which leads to the loss of its catalytic activity. Secondly, in the samples of $\mathrm{NiFe}_{2} \mathrm{O}_{4}+$ polymer $\left(700{ }^{\circ} \mathrm{C}\right)$ and $\left(900{ }^{\circ} \mathrm{C}\right)$ after thermal and electrochemical reduction, the composites are formed consisting of reduced iron $\left(\mathrm{Fe}^{0}\right)$, Fe-Ni-alloys, possibly reduced nickel and magnetite residues (Fig. 2 and 3). According to previously performed experiments, iron skeleton catalysts were practically inactive in the electrohydrogenation of $\mathrm{APh}$. Therefore, the reduced iron should not exhibit high electrocatalytic activity in the studied process unless it interacts with other components of the composite as with carriers. Magnetite also did not catalyze the electrohydrogenation of $\mathrm{APh}$. In this case, particles of Fe-Ni-alloys are formed with various compositions, but with a predominant iron content, as it was shown by X-ray spectral analyzes. And such Fe-Ni-particles exhibited low electrocatalytic activity in the electrohydrogenation of APh.

\section{Conclusions}

Nickel ferrite $\left(\mathrm{NiFe}_{2} \mathrm{O}_{4}\right)$ samples were obtained by co-precipitation method without and with the addition of polymer stabilizers (PVP, PVA) followed by heat treatment at $500{ }^{\circ} \mathrm{C}, 700{ }^{\circ} \mathrm{C}$ and $900{ }^{\circ} \mathrm{C}$. XRD analysis shown that as a result of heat treatment of $\mathrm{NiFe}_{2} \mathrm{O}_{4}+$ polymer samples, the nickel and iron partial reduction occurred due to the thermal decomposition products of polymer stabilizers of low content. The resulting FeNi-composites possessed magnetic properties and exhibited low electrocatalytic activity in the electrohydrogenation of acetophenone, obviously caused by the structure of Fe-Ni-alloys particles with predominant iron content.

This work was financially supported by the Ministry of Education and Science of the Republic of Kazakhstan (Scientific and Technical Program No. BR05236438)

\section{References}

1 Lim Ch.W. Magnetically recyclable nanocatalyst systems for the organic reactions / Ch.W. Lim, I.S. Lee // Nano Today. 2010. - Vol. 5, No. 5. - P. 412-434.

2 Kharisov B.I. Mini-review: Ferrite nanoparticles in the catalysis / B.I. Kharisov, H.V. Rasika Dias, O.V. Kharisova // Arabian J. Chem. - 2014. - Vol. 12, No. 7. - P. 1234-1246.

3 Ghaani M. Synthesis of $\mathrm{CuFe}_{2} \mathrm{O}_{4}$ nanoparticles by a new co-precipitation method and using them as efficient catalyst for onepot synthesis of naphthoxazinones / M. Ghaani, J. Saffari // J. of Nanostructures. — 2016. — Vol. 6, No. 2. — P. $172-178$. 
4 Dandia A. Magnetically separable $\mathrm{CuFe}_{2} \mathrm{O}_{4}$ nanoparticles: an efficient catalyst for the synthesis of quinoxaline derivatives in tap-water under sonication / A. Dandia, R. Singh, J. Joshi, S. Maheshwari // European Chem. Bull. — 2013. — Vol. 2, No. 10. — P. 825-829.

5 Goldman A. Modern Ferrite Technology. $2^{\text {nd }}$ Edition / A. Goldman. — Pittsburgh, USA: Springer Science, 2006. — 438 p.

6 Ghasemi A. Synthesis of novel $\mathrm{NiFe}_{2} \mathrm{O}_{4}$ nanospheres for high performance pseudocapacitor applications / A. Ghasemi, M. Kheirmand, H. Heli // Russ. J. Electrochem. — 2019. - Vol. 55, No. 3. - P. 206-214.

7 Gao X. Morphology-controllable preparation of $\mathrm{NiFe}_{2} \mathrm{O}_{4}$ as high performance electrode material for supercapacitor / X. Gao, W. Wang, J. Bi, Y. Chen, X. Hao, X. Sun, J. Zhang // Electrochim. Acta. — 2019. — Vol. 296, No. 2. — P. 181-189.

8 Kavas H. Characterization of $\mathrm{NiFe}_{2} \mathrm{O}_{4}$ nanoparticles synthesized by various methods / H. Kavas, N. Kasapoğlu, A. Baykal, Y. Köseoğlu // Chem. Pap. - 2009. — Vol. 63, No. 4. - P. 450-455.

9 Godbole B. Synthesis, structural, electrical and magnetic studies of Ni-ferrite nanoparticles / B. Godbole, N. Badera, S.B. Shrivastava, D. Jain, S. Chandra, V. Ganesan // Physics Procedia. - 2013. - Vol. 49. - P. 58-66.

10 Nejati K. Preparation and magnetic properties of nanosize nickel ferrite particles using hydrothermal method / K. Nejati, R. Zabihi // Chem. Central J. — 2012. - Vol. 6, No 1. — P. 1-6.

11 Singh S. Nanosize dependent electrical and magnetic properties of $\mathrm{NiFe}_{2} \mathrm{O}_{4}$ ferrite / S. Singh, N.K. Ralhan, R.K. Kotnala, K.C. Verma // Indian J. Pure Appl. Phys. - 2012. — Vol. 50, No. 10. — P. 739-743.

12 Shanmugavel T. Cost effective preparation and characterization of nanocrystalline nickel ferrites $\left(\mathrm{NiFe}_{2} \mathrm{O}_{4}\right)$ in low temperature regime / T. Shanmugavel, S. Gokul Raj, G. Ramesh Kumar, G. Rajarajan, D. Saravanan // Journal of King Saud University - Science. - 2015. - Vol. 27, No. 2. - P. 176-181.

13 Prokopenko S.L. Electrophysical properties of polymeric nanocomposites based on cobalt and nickel ferrities modified with copper iodide / S.L. Prokopenko, R.V. Mazurenko, G.M. Gunja, N.V. Abramov, S.M. Makhno, P.P. Gorbyk // J. Magn. Magn. Mater. - 2020. - Vol. 494. - P. 1-6.

14 Sivakumar P. Synthesis and characterization of $\mathrm{NiFe}_{2} \mathrm{O}_{4}$ nanoparticles and nanorods / P. Sivakumar, R. Ramesh, A. Ramanand, S. Ponnusamy, C. Muthamizhchelvan // J. Alloys Compd. - 2013. - Vol. 563. - P. 6-11.

15 Kurosawa R. Promotion of grain growth in $\mathrm{NiFe}_{2} \mathrm{O}_{4}$ by annealing with oleic acid / R. Kurosawa, T. Suzuki, T. Nakayama, H. Suematsu, K. Niihara, K. Jeong, K.H. Kim // Current Appl. Phys. - 2012. - Vol. 12, No. 2. - P. 68-70.

16 Васильев В.П. Практикум по аналитической химии / В.П. Васильев, Р.П. Морозова, Л.А. Кочергина. - М.: Химия, 2000. $-328 \mathrm{c}$.

17 Юрист И.М. Селективное комплексонометрическое титрование / И.М. Юрист, М.М. Талмуд. — М.: Наука, 1993. $232 \mathrm{c}$.

\title{
Я.А. Висурханова, Е.А. Соболева, Н.М. Иванова, З.М. Молдахметов
}

\section{Полимерлік тұрақтандырғыштардың әсерімен никель ферритін (II) термиялық және электрохимиялық қалпына келтіру}

\begin{abstract}
Никель (II) ферритінің үлгілері сулы ерітіндіде полимерлі тұрақтандырғыштарды (поливинил спирті және поливинилпирролидон) қоспай және қосу арқылы металл тұздарын бірге тұндырумен және оларды одан әрі $500{ }^{\circ} \mathrm{C}, 700{ }^{\circ} \mathrm{C}$ және $900{ }^{\circ} \mathrm{C}$ кезінде термиялық өңдеуімен алынған. Олардың құрылымдық-фазалық өзгерістері ацетофенонды электргидрлеуде оларды катализаторлар ретінде қолдануға дейін және қолданғаннан кейін рентгенофазалық талдау әдісімен анықталған. Алынған үлгілердің $\mathrm{NiFe}_{2} \mathrm{O}_{4}$ және $\mathrm{NiFe}_{2} \mathrm{O}_{4}+$ полимер морфологиялық ерекшеліктері электрондық микроскопия әдістерімен зерттелген. Полимерлі тұрақтандырғышты бірге тұндыру ортасына енгізу және оның прекурсорлар (металдар гидроксидтері және оксидтері) мен қалыптасатын никель (II) ферриті құрамында жартылай сақталуы алынған үлгілердің құрылымдық-фазалық құрамына айтарлықтай әсер ететіні анықталған. Фазалық құрамдардағы айырмашылықтар осы үлгілердің термиялық өңдеу температурасымен де анықталады. Тұрақтандырғыштарсыз синтезделген никель ферритіне қарағанда $\mathrm{NiFe}_{2} \mathrm{O}_{4}+$ полимер үлгілері термиялық өңдеу барысында және құрамында Ni- және Fe-Ni-композиттерін қалыптастыра отырып электрохимиялық жүйеде жартылай тотықсыздады. Қалпына келтірілген никель (II) ферритінің үлгілері ацетофенонды электрогидрлеуде электрокаталитикалық қасиеттердің пайда болу қабілетіне зерттелген. Өткізілген тәжірибелер арқылы осы үдерісте олардың әлсіз электрокаталитикалық қасиеттері анықталды, ол құрамында басым бөлігі темір болатын $\mathrm{Fe}-\mathrm{Ni}$-балқыма бөлшектерінің құрылысымен, сондайақ никель бөлшектерінің белсенділігін тежейтін магнетиттің болуымен түсіндірілген.
\end{abstract}

Кілт сөздер: никель ферриті (II), тұндыру әдісі, термиялық өндеу, электрохимиялық қалпына келтіру, никель мен темірдің нуль-валентті бөлшектері, электрокаталитикалық гидрирлеу, ацетофенон. 


\title{
Я.А. Висурханова, Е.А. Соболева, Н.М. Иванова, 3.М. Мулдахметов \\ Термическое и электрохимическое восстановление феррита никеля (II) под влиянием полимерных стабилизаторов
}

\begin{abstract}
Образцы феррита никеля (II) получены совместным соосаждением солей металлов в водном растворе без и с добавлением полимерных стабилизаторов (поливинилового спирта и поливинилпирролидона) и дальнейшей термической обработкой при $500{ }^{\circ} \mathrm{C}, 700{ }^{\circ} \mathrm{C}$ и $900{ }^{\circ} \mathrm{C}$. Методом рентгенофазового анализа выявлены их структурно-фазовые изменения до и после применения их в качестве катализаторов в электрогидрировании ацетофенона. Морфологические особенности полученных образцов $\mathrm{NiFe}_{2} \mathrm{O}_{4}$ и $\mathrm{NiFe}_{2} \mathrm{O}_{4}+$ полимер исследованы методом электронной микроскопии. Установлено, что введение полимерного стабилизатора в среду соосаждения и частичное сохранение его в составе прекурсоров (гидроксидов и оксидов металлов) и формирующегося феррита никеля (II) оказывают заметное влияние на структурно-фазовый состав полученных образцов. Отличия в фазовых составах определяются также температурой термической обработки этих образцов. Показано, что, в отличие от феррита никеля, синтезированного без стабилизаторов, образцы $\mathrm{NiFe}_{2} \mathrm{O}_{4}+$ полимер частично восстанавливаются в ходе термической обработки и дополнительно в электрохимической системе с образованием Ni- и Fe-Ni-coдержащих композитов. Восстановленные образцы феррита никеля (II) исследованы на способность к проявлению электрокаталитических свойств в электрогидрировании ацетофенона. Проведенными экспериментами установлены их слабые электрокаталитические свойства в этом процессе, предположительно обусловленные строением частиц $\mathrm{Fe}-\mathrm{Ni}$-сплавов с преобладающим содержанием железа, а также присутствием магнетита, ингибирующего активность частиц никеля.
\end{abstract}

Ключевые слова: феррит никеля (II), метод соосаждения, термическая обработка, электрохимическое восстановление, нуль-валентные частицы никеля и железа, электрокаталитическое гидрирование, ацетофенон.

\section{References}

1 Lim, Ch.W., \& Lee, I.S. (2010). Magnetically recyclable nanocatalyst systems for the organic reactions. Nano Today, 5(5), 412-434.

2 Kharisov, B.I., Rasika Dias, H.V., \& Kharisova, O.V. (2019). Mini-review: Ferrite nanoparticles in the catalysis. Arabian J. Chem., 12(7), 1234-1246.

3 Ghaani, M., \& Saffari, J. (2016). Synthesis of $\mathrm{CuFe}_{2} \mathrm{O}_{4}$ nanoparticles by a new co-precipitation method and using them as efficient catalyst for one-pot synthesis of naphthoxazinones. J. of Nanostructures, 6(2), 172-178.

4 Dandia, A., Singh, R., Joshi, J., \& Maheshwari, S. (2013). Magnetically separable $\mathrm{CuFe}_{2} \mathrm{O}_{4}$ nanoparticles: an efficient catalyst for the synthesis of quinoxaline derivatives in tap-water under sonication. European Chem. Bull., 2(10), 825-829.

5 Goldman, A. (2006). Modern Ferrite Technology. Pittsburgh, USA: Springer Science.

6 Ghasemi, A., Kheirmand, M., \& Heli, H. (2019). Synthesis of novel $\mathrm{NiFe}_{2} \mathrm{O}_{4}$ nanospheres for high performance pseudocapacitor applications. Russ. J. Electrochem., 55(3), 206-214.

7 Gao, X., Wang, W., Bi, J., Chen, Y., Hao, X., Sun, X., \& Zhang, J. (2019). Morphology-controllable preparation of $\mathrm{NiFe}_{2} \mathrm{O}_{4}$ as high performance electrode material for supercapacitor. Electrochim. Acta, 296(2), 181-189.

8 Kavas, H., Kasapoğlu, N., Baykal, A., \& Köseoğlu, Y. (2009). Characterization of $\mathrm{NiFe}_{2} \mathrm{O}_{4}$ nanoparticles synthesized by various methods. Chem. Pap., 63, 450-455.

9 Godbole, B., Badera, N., Shrivastava, S.B., Jain, D., Chandra, S., \& Ganesan, V. (2013). Synthesis, structural, electrical and magnetic studies of Ni-ferrite nanoparticles. Physics Procedia, 49, 58-66.

10 Nejati, K., \& Zabihi, R. (2012). Preparation and magnetic properties of nanosize nickel ferrite particles using hydrothermal method. Chemistry Central Journal, 6(1), 1-6. http://dx.doi.org/10.1186/1752-153X-6-23.

11 Singh, S., Ralhan, N.K., Kotnala, R.K., \& Verma, K.C. (2012). Nanosize dependent electrical and magnetic properties of $\mathrm{NiFe}_{2} \mathrm{O}_{4}$ ferrite. Indian J. of Pure Appl. Phys., 50(10), 739-743.

12 Shanmugavel, T., Gokul Raj, S., Ramesh Kumar, G., Rajarajan, G., \& Saravanan, D. (2015). Cost effective preparation and characterization of nanocrystalline nickel ferrites $\left(\mathrm{NiFe}_{2} \mathrm{O}_{4}\right)$ in low temperature regime. Journal of King Saud University - Science, 27(2), 176-181.

13 Prokopenko, S.L., Mazurenko, R.V., Gunja, G.M., Abramov, N.V., Makhno, S.M., \& Gorbyk, P.P. (2020). Electrophysical properties of polymeric nanocomposites based on cobalt and nickel ferrities modified with copper iodide. J. Magn. Magn. Mater., 494, 1-6. https://doi.org/10.1016/j.jmmm.2019.165824

14 Sivakumar, P., Ramesh, R., Ramanand, A., Ponnusamy, S., \& Muthamizhchelvan, C. (2013). Synthesis and characterization of $\mathrm{NiFe}_{2} \mathrm{O}_{4}$ nanoparticles and nanorods. J. Alloys Compd., 563, 6-11.

15 Kurosawa, R., Suzuki, T., Nakayama, T., Suematsu, H., Niihara, K., Jeong, K., \& Kim, K.H. (2012). Promotion of grain growth in $\mathrm{NiFe}_{2} \mathrm{O}_{4}$ by annealing with oleic acid. Current Applied Physics, 12 (2), 68-70.

16 Vasilev, V.P., Morozova, R.P., \& Kochergina, L.A. (2000). Praktikum po analiticheskoi khimii [Workshop on analytical chemistry]. Moscow: Khimiia [in Russian].

17 Yurist, I.M., \& Talmud, M.M. (1993). Selektivnoe kompleksonometricheskoe titrovanie [Selective complexometric titration]. Moscow: Nauka [in Russian]. 